\title{
Who Doesn't Want to Share Leadership? The Role of Personality, Control Preferences, and Political Orientation in Preferences for Shared vs. Focused Leadership in Teams
}

\author{
Anna Olga Kuzminska*, Dominic Schulze**, \& Anna Koval ${ }^{* * *}$
}

\begin{abstract}
Summary
An increasing number of institutions decide to adopt the premises of shared or distributed leadership models and reduce the level of organizational hierarchy. Such models were shown to positively affect employee well-being, creativity, and - indirectly - effectiveness. However, while shared leadership assumes a relatively equal division of control in interdependent situations, some people display preferences to dominate or submit. What is more, unequal/equal division of power may be preferable to people with a more conservative/liberal political orientation. In the current research we examine whether the shared leadership model is likely to be equally attractive to all employees. We focus on the effect of personality traits, control preferences, and political orientation on preferences for shared vs. focused leadership. One-hundred-and-eighty-four participants declared their team preferences (focused vs. shared leadership), as well as answered questions regarding their personality (HEXACO), control preferences, and political orientation through the Amazon Mechanical Turk platform. Control preferences, as well as political orientation were related to preferences for shared vs. focused leadership. Specifically, while dominance and conservative political orientation was associated with higher preference for focused leadership, collaboration predicted higher preference for shared leadership. Personality traits did not predict the preferences for focused vs. shared leadership.
\end{abstract}

Keywords: shared leadership, distributed leadership, teal organizations, HEXACO, control preferences, political orientation

JEL: M12, O15, J24, J28

\section{INTRODUCTION}

The first action of Ricardo Semler, when he first took over SEMCO (Semler and Co., a manufacturing company founded by his father), was to fire all senior managers. Semler challenged the status quo and asked questions such as: Why should a few managers decide on the allocation of parking slots or office desks, or what the new shop floor or social area should look like, instead of letting the employees decide on their own? Why is the management board a closed group - can we keep 1-2 seats free in each session for the first employee who asks to join and be the voice of the other workers? Why shouldn't all members of the organization take a share of the leadership (including decision making and responsibility) within the group, team, or organization (Semler, 2001)?

Semler was not the only one to question the organizational status quo. Frederic Laloux (2014) identified similar examples, listing so-called teal organizations that emphasize - among others - self-management in their activities. In consequence, they choose a leadership style that is more distributed or shared. While having little or no formal hierarchy, these organizations seem to be highly effective and outstanding in customer and employee satisfaction (Laloux, 2014; Semler, 2001).

Faculty of Management, University of Warsaw, Poland, https://orcid.org/0000-0002-6060-4549, e-mail: akuzminska@ wz.uw.edu.pl

** Faculty of Management, University of Warsaw, Poland, https://orcid.org/0000-0001-7314-2737, e-mail: Dominic.Schulze@ gmx.de

*** Faculty of Management, University of Warsaw, Poland, https://orcid.org/0000-0002-8192-762X, e-mail: Koval.anna.v@ gmail.com 
Scientific interest in these new forms of management comes at a time when more and more studies point at the interpersonal risks of having power over others. Those in power are more likely to treat others as means to their ends, take risks, categorize others, and break social norms (e.g. Anderson, \& Galinsky 2006; Bendahan, Zehnder, Pralong, Antonakis, 2015; Fiske, 1993). They are less trustful, cooperative, and empathetic - which is even evident in their brain responses (e.g. Gonzaga, Keltner, \& Ward 2008; Guinote, Judd, \& Brauer, 2002; Hogeveen, Inzlicht, \& Obhi, 2014; Keltner, Gruenfeld, \& Anderson, 2003; Kipnis, 1972; van Kleef, Oveis, van der Löwe, LuoKogan, Goetz, \& Keltner, 2008). Maybe sharing leadership within a team or an organization is one way of counteracting these negative effects by balancing the source of power?

In the scientific literature, the phenomenon of shared leadership is still relatively new and understudied. Although incoming research results suggest its positive consequences on performance, innovation, and employee satisfaction (e.g. Ensley, Hmieleski, \& Pearce, 2006; Hoch, 2013; Wang et al., 2013), it is not certain what is the role of situational or individual difference factors (such as employees' personalities or preferences). Not everyone likes to take on additional responsibilities. Some people like clear hierarchical structures (e.g. Grzelak, 2001). Would such people feel comfortable participating in shared leadership?

\section{AIM OF THE STUDY}

The aim of the current paper is twofold. First, in order to reduce the definitional chaos observable in the literature, we try to untangle the concept of shared leadership, as well as review its antecedents and consequences towards organizational outcomes and employee wellbeing. Second, we investigate whether shared leadership is equally preferred by everyone. In other words, are there individual differences that could predict preference for such an organizational model? Since this subject has not yet - to our knowledge - been undertaken in empirical research, we start by focusing on three factors - personality, control preferences, and political orientation as predictors of preference for shared vs. focused leadership in teams.

\section{THEORETICAL BACKGROUND}

\section{Shared Leadership as a Form of Collective Leadership}

The broadest definition of shared leadership is that of the plurality of leadership: the combined influence of multiple leaders in specific organizational situations. Collective forms of leadership started to gain more research attention some 2-3 decades ago and are becoming a more and more prominent subject of research in the leadership domain (e.g. Denis, Langley, \& Sergi 2012; Gibb, 1954; Gronn, 2002; Lord, Day, Zaccaro, Avolio, \& Eagly, 2017; Pearce, 2007; Thorpe, Gold, \& Lawler, 2011). The focus was shifted from an individual, trait based approach to leadership to that of a continuum between focused and shared/distributed leadership (Gibb, 1954). On this continuum:

- concentrated and focused leadership refers to a dominant influence by one person, while

- distributed or shared leadership refers to mutual \& reciprocal influence of different participants.

Over the last decades a number of concepts and terminologies were used to describe collective forms of leadership within a team or an organization (see Table 1 and the review of Ulhøi \& Müller, 2014). However, the most commonly used terminologies are: distributed leadership and shared leadership. Although the meaning of those two concepts is to a large extent the same and they are sometimes used interchangeably (Goksoy, 2016), for our purposes we decided to use the concept of shared leadership, because it is most recognized in management literature. In the current work we will understand shared leadership as: 
"A dynamic, interactive influence process among individuals in groups for which the objective is to lead one another to the achievement of group or organizational goals or both. This influence process often involves peer, or lateral influence and at other times involves upward or downward hierarchical influence" (Pearce \& Conger, 2003, p. 1).

Importantly, the existence of shared leadership does not mean the absence of vertical leadership (Pearce \& Sims, 2002). These two concepts exist in parallel, which means that "group members actively and intentionally shift the role of a leader to one another as necessitated by the environment or circumstances in which the group operates" (Pearce, Hoch, Jeppesen, \& Wegge, 2010, p. 151) no matter of the level of verticality of the leadership structure. Also, it might involve a certain degree of supervision from a vertical or an external leader, balanced with a certain degree of team's selfdirection (Gibb, 1954).

Table 1. Diffrent concepts of collective forms of leadership in the literature (Ulhøi et al., 2014)

\begin{tabular}{|c|c|}
\hline Concept & Author(s) \\
\hline Shared cognition & Ensley \& Pearce, 2001 \\
\hline Distributed leadership & Barry, 1991; Brown et al., 2002 \\
\hline Participative leadership & Bass, 1990, in Carte et al., 2006; Collins, 1995 \\
\hline Relational leadership & Uhl-Bien, 2006 \\
\hline Participatory management & Wu, Lee, 2001 \\
\hline Concertive action & Gronn, 2002 \\
\hline Collectiveleadership & Denis et al., 2001; Hiller et al., 2006 \\
\hline Collaborative leadership & Finch, 1977; Vangen et al., 2003 \\
\hline Collaborativegovernance & Huxham et al., 2000 \\
\hline Informal leadership & McCrimmon, 2005 \\
\hline Emergent leadership & Pearce \& Sims, 2002 \\
\hline Co-leadership & Sally, 2002 \\
\hline Dual leadership & Etzioni, 1965; Etzioni et al., 1968 \\
\hline Split management & Choi \& Beamish, 2004 \\
\hline Connective leadership & Klakovich, 1994, 1996 \\
\hline
\end{tabular}

Shared/distributed leadership follows three premises (Bennett, Wise, Woods, \& Harvey, 2003).

- It is not just a result of structural relationships, but emerges through a network of interacting individuals, contributing their initiative and expertise in a variety of ways over time.

- The boundaries of leadership are open, which allows to constantly raise the question of "Who" will be the leader. A leader can be found within, but also outside of the respective group.

- Expertise is distributed across many members of the team. Leadership capabilities and perspectives are distinct, numerous, and spread within the group of individuals. The result is more than the sum of the individual contributions. 


\section{Consequences of Shared Leadership}

In order to be competitive in terms of effectiveness and innovativeness, organizations need to leverage their human and social capital. Although yet understudied, research already indicates shared leadership as a strong candidate to address these challenges. "As organizations have steadily progressed into the knowledge economy we can no longer rely on simple notions of top-down, command-and-control leadership, based on the idea that workers are merely interchangeable drones" (Pearce, 2007, p. 1).

Creativity and innovation. Shared leadership environments enable employees to enact their collective psychological capital and support knowledge sharing, which leads to a more participative and innovative organizational culture (Nonaka, Hirose, \& Takeda, 2016). For example, shared leadership was found to be a predictor of a teams' level of innovative behavior (Hoch, 2013). Shared leadership was also found to positively impact creativity on a team and individual level a relationship partially mediated by knowledge sharing (Gu, Chen, Huang, Liu, \& Huang 2018; Lee, Lee, \& Seo, 2015). On a team level, these effects were even more pronounced when tasks required greater interdependence (Gu et al., 2018).

A study of engineering design teams found that creativity within the team was higher when the team leadership network was high in density and low in centrality - indicators of the distribution of leadership activities (Wu \& Cormican, 2016). The more leadership ties between team members in the network, the higher is the density of the leadership network. A higher density is predictive of more knowledge sharing and higher creativity. The more the network is dominated by one or a few members of the team, the more centralized it is. Lower centralization predicts higher cooperation among team members. Shared leadership may contribute towards increasing the level of creativity, also by weakening the negative effects of team conflicts (relational conflicts and task conflicts) (Hu, Chen, Gu, Huang, \& Liu, 2017).

Effectiveness and performance. Compared to focused leadership approaches, shared leadership was shown to be a better predictor of higher performance, although the relationship seems to be indirect (Han, Lee, Beyerlein, \& Kolb, 2018; Mathieu, Kukenberger, D’innocenzo, \& Reilly, 2015; Robert \& You, 2018). Research indicated that the relationship is mediated by team cohesion (Mathieu et al., 2015), team-satisfaction (Robert et al., 2018), coordination activities, goal commitment, and knowledge sharing (Han et al., 2018). A meta-analysis on team-cohesion and performance in teams varying in their level of shared leadership suggested that higher levels of team-cohesion predict higher performance (Mathieu et al, 2015). While shared leadership had no direct impact on performance, it played an important role in enhancing team-cohesion.

Similarly, surveys conducted among graduate and undergraduate students in project teams indicated that shared leadership indirectly affected teams' performance through coordination activities, goal commitment, and knowledge sharing (Han et al., 2018). Other studies supported the positive effect of shared leadership on performance. Shared leadership was shown to work better than vertical leadership in change management teams (Pearce \& Sims, 2002), new venture top management teams (Ensley et al., 2006), and virtual teams (Hoch \& Kozlowski, 2014).

Employee well-being. Compared to focused leadership, shared leadership predicted lower levels of conflict and greater consensus, as well as higher intragroup trust and cohesion in teams (Bergman, Rentsch, Small, Davenport, \& Bergman, 2012). It was also shown to facilitate team satisfaction in virtual teams and moderate the impact of trust and autonomy on satisfaction (Robert et al., 2018). In creative contexts, shared leadership mediated the relationship task and team characteristics (such as task cohesion) and task satisfaction (Serban \& Roberts, 2016). In a study of top management team members in Christian church organizations shared leadership negatively related to team member role overload, role conflict, role ambiguity, and job stress (Wood \& Fields, 2007). It was also positively related to job satisfaction. 


\section{The antecedents of Shared Leadership}

Since shared leadership was shown to give rise to many of the above-mentioned positive organizational consequences, research investigated factors facilitating its emergence. So far, the antecedents of shared leadership emergence uncovered by scholars include supporting team and organizational factors and behaviors of vertical leaders.

Team and organizational factors. Internal team environment, interdependence and team integrity, as well as task cohesion and ambiguity were identified in the literature as the antecedents of shared leadership on a team and organizational level.

Internal team environment. The overall team environment comprised of shared purpose, social support, and voice was shown to enable shared leadership emergence in teams (e.g. Carson, Tesluk, \& Marrone, 2007; Daspit, Tillman, Boyd, \& Mckee, 2013). These three dimensions collectively create a context, in which team members are more open to offer their own leadership and to rely on other members' leadership. Shared purpose is a sense of similar understanding of the primary objectives among team members. Social support is a mutual emotional and psychological support of each other. Voice is a degree of participation and input into the team's purpose. Voice is also associated with participative behaviors, such as being part of the decision-making process and debating around alternative approaches to the team's procedures and tasks. Several studies confirmed the positive relationship between internal team environment and the level of shared leadership in a team (e.g. Carson et al., 2007; Daspit et al., 2013).

Interdependence and team integrity. Interdependence is defined as a degree to which team members rely and depend on the skills of others and interact to complete the team's tasks. Interdependence was found to be positively related to shared leadership emergence by enhancing solidarity among team members (Fausing, Joensson, Lewandowski, \& Bligh, 2015). Team integrity, also referred to as social responsibility, consists of reliability and trustworthiness which enable transparent communication among team members. If team members show a higher level of reliability and trust, as well as a tendency to behave fairly, ethically and transparently, the emergence of shared leadership is more likely (Hoch, 2013).

Task cohesion and ambiguity. Task cohesion is defined as a team's shared interest in a task, based on the collective perception of skillfulness and ability to perform the task. Task ambiguity appears when team members carry out their roles in the absence of necessary task-related information. It was found that task cohesion facilitates the emergence of shared leadership, while task ambiguity impedes it (Serban \& Roberts, 2016). Shared leadership affected team and task satisfaction only when task ambiguity was low.

Vertical leadership behaviors. As mentioned above, shared leadership does not necessitate a context devoid of any form of vertical leadership, as it exists on a continuum (Gibb, 1954). The sharing of leadership and verticality of leadership are independent constructs (a team could be very high or very low on both of these dimensions). Such a vertical leadership can, however, either facilitate or impede the emergence of shared leadership in an organization or a team, as presented below.

External leadership. External leadership is a guidance provided by a leader within an organization, who is not a part of the team. For instance, in the study of Carson et al. (2007), an external leader acted as a partner in a consulting organization, helping to supervise multiple projects. It was shown that coaching by an external leader may enable shared leadership by providing encouragement and reinforcement (Carson et al., 2007). External leaders may use these strategies when team members demonstrate leadership behaviors.

Additionally, fair rewards strategy was shown to directly influence shared leadership by stimulating and initiating team members' participation (Grille, Schulte, \& Kauffeld, 2015). External leaders can provide general encouragement, help when internal conflicts arise, and - if needed suggest or contribute to the team's strategies and processes (see also: Carson et al., 2007). 
Vertical empowering leadership. Vertical empowering leadership can be carried out by an external or internal leader and can be performed on a regular basis or when needed. Such a leader provides motivational support and empowerment to the team members. Studies on the relationship between vertical empowering leadership and the emergence of shared leadership show mixed results. Some document a positive effect of empowering leadership on shared leadership (Fausing et al., 2015; Hoch, 2013), while others find no effect whatsoever (Grille et al., 2015).

Leader humility. Leader humility signifies a leader's willingness to admit to their own mistakes, be open to advice, ideas, and feedback from other employees, as well as highlight team members' unique skills. Leader humility was shown to stimulate the interaction between leaders and followers and - as a result - contribute to the development of shared leadership (Chiu, Owens, \& Tesluk, 2016). Consequently, to facilitate the development of shared leadership in teams, a leader should: (1) admit the lack of knowledge or expertise, (2) acknowledge that someone else has more knowledge or skills, and (3) be open to new ideas.

Transformational leadership and gatekeeping leadership. Transformational leadership is focused on strengthening the motivation and morale of team members, whereas gatekeeping leadership is based on a leader's ability to perform internal and external communication effectively. This ability is exemplified by using external communication skills to acquire technical information and transmit it to the team members (Ishikawa, 2012).

Gatekeeping leadership (but not transformational leadership) was shown to positively affect the emergence of shared leadership (Ishikawa, 2012). Also, results suggest that gatekeeping leadership is promoting the internal and external communication of team members, which encourages them to display leadership behaviors, and consequently, enhances a shared leadership environment.

\section{Who Does Not Want to Share Leadership?}

Prior literature has advanced our knowledge on consequences and antecedents of shared leadership. However, one question remains unattended: Is everyone equally willing to work in shared leadership environments? Prior literature largely ignores potential individual differences in whether people desire share leadership in an organizational context. Given our knowledge on a variety of social orientations, control preferences, habits, and situational factors people's willingness to get involved in leadership activities might be dramatically affected. To function properly, shared leadership teams need - to a much greater extent than hierarchically governed teams - highly involved individuals. Individuals who are willing to balance between taking control (when the team needs direction) and letting go of control (when other team members oppose one's idea). People who do not believe in a given management method (especially if it involves change) are likely to engage in counterproductive behaviors. In the current study we would like to look at three sets of factors that might predict people's preference for shared vs. focused leadership - personality, control preferences, and political orientation. The rationales for this selection are provided below.

Control preferences. Control over our environment enables us to reach desired outcomes avoid events we consider unpleasant and obtain things we desire. However, previous research shows that being in control is not equally attractive to everyone (Grzelak, 2002). Some people prefer to submit to control of others, especially in the context of uncertainty, as predicted by the theory of Defensive Orientation (Dolinski, 1993). Getting rid of personal control protects one's self-esteem by transferring the responsibility for the potentially negative outcomes of the situation to a different agent (Dolinski, 1993; Zinserling \& Winiewski, 2011).

In the current study we adopt the framework of control preferences developed by Grzelak (2001) and based on Kelley and Thibaut's (1978) theory of interdependence. Control preferences signify 
a relatively stable (but situationally dependent) inclination towards a certain division of control in an interdependent situation. Each interdependent actor, in an interaction with others might try to intensify:

1) “one's control over one's own outcomes: self-control preference (proactive autonomy)

2) one's control over others' outcomes: power preference (dominance)

3) others' control over one's own outcomes: dependence preference (submissiveness)

4) others' control over others' own outcomes: respect preference (respect for autonomy)

5) joint, one's and others' control over one's own and others' outcomes: collaboration preference"' (Grzelak, 2001).

Studies of Grzelak (2001) indicated one additional preference - that of reactive autonomy, characterized by strong reactance or a lack of acceptance for others' control over one's own outcomes.

Control preferences determine the interest of individuals to stay in, or to exit from, the particular relationship or situation (Grzelak, Kuhlman, Yeagley, \& Joireman, 2010). For instance, some will look for jobs which allow them to control both own and other people's outcomes, while others will prefer to give up control to a competent boss. Indeed, dominance predicts placing greater value at success and job promotion (Modrzejewska, 2004), while collaboration is related to a higher pro-ecological orientation (Grzelak, 2002), which is characterized by a joint social effort.

Based on the above, we predict collaboration to be positively related to shared leadership preference, with dominance and submissiveness positively related to focused leadership preference. With respect to the autonomy scales, it is not easy to predict a clear direction. On one hand, those with high preference for autonomy might want to share leadership in teams because of the willingness to influence their own outcomes (proactive autonomy) and to respect others' independence (respect for autonomy). On the other hand, being in a shared leadership team requires giving up at least some degree of control as one needs to allow other members of the team to influence one's outcomes as well. This might reduce the perceived control over the situation to a similar or greater extent than in focused leadership teams. In a focused leadership team one needs to win over one boss, in a shared leadership team there is a need to convince a greater number of team members to one's point of view. Finally, individuals high in reactive autonomy might want to reduce the possibility for any sort of interdependence.

\section{H1: Control preferences predict preference for shared leadership in teams.}

H1a: Higher preferences for collaboration predicts higher preference for shared leadership in teams.

H1b \& H1c: Higher preferences for (b) submissiveness and (c) dominance predict higher preference for focused leadership in teams.

Political orientation. In the current study we treat political orientation as a proxy for a variety of opinions on social and economic issues it was shown to predict (Jost, 2006). For instance, conservatives are more likely to believe that individuals need to be constrained by authorities and rules to guarantee social order (Sowell, 2002). They prefer familiarity, stability, and predictability (McCrae, 1996), are more resistant to change and likely to accept inequality (Jost, Glaser, Sulloway, \& Kruglanski, 2003; Pratto, Sidanius, Stallworth, \& Malle, 1994). Such believes might predict a higher preference for more traditionally adopted focused leadership, in which order is guaranteed by a hierarchical structure.

Grzelak (2001) distinguishes between two collaboration preferences: (1) joint, one's and others' control over one's own outcomes: collaboration preference A and (2) joint, one's and others' control over others' outcomes: collaboration preference B". 
Liberals, on the other hand, are more likely to believe that individuals should have as much influence over own lives as possible without hurting others (Sowell, 2002). They were also shown to be more open to experience, and endorse change and novelty (McCrae, 1996). It is, therefore, reasonable to expect that liberals would endorse the novelty of the shared leadership approach as a means to greater self-expression of individual team members.

\section{H2: Conservative political orientation predicts higher preferences for focused leadership in teams.}

Personality. In the current study we also explore the relationship between personality traits and preference for shared vs. focused leadership. Shared leadership teams need to function in a climate of constant collaboration, engagement, and a need to balance the needs and visions of all team members. Because of that, we believe that such an environment might be easier to deal with by extraverts rather than introverts because of their participative and communicative nature and lower emotional reactivity (McCrae \& John, 1992). What is more, openness to experience, which involves curiosity, openness to new ideas, and adaptability to changing situations might predict higher willingness to try a different style of management (McCrae \& John, 1992). Finally, emotional stability, associated with higher leadership performance expectations and higher stress-resistance (McCrae \& John, 1992), might predict better compatibility with complex team environments, such as teams with shared leadership.

However, it is not clear whether personality traits are associated with preferences for different environments, since people are often unaware of their internal states (Lambie \& Marcel, 2002). It is possible that people of certain personality traits feel and fare worse in shared/focused leadership environments, but are unaware of their psychophysiological costs beforehand. For this reason, our inclusion of personality traits in this study is merely exploratory.

\section{METHOD}

\section{Participants}

We recruited one-hundred and eighty four participants $(63 \%$ men, ages $20-71, \mathrm{M}=33.48$, $\mathrm{SD}=10.41$, median $=30$ years) via the Amazon Mechanical Turk platform. None were excluded. Most participants were currently employed (80.4\% full-time, $10.9 \%$ part-time). Mturk participants were all US nationals. Data was collected between August, 24, 2018 and August, 30, 2018. Due to recent reports of automated responses to Mturk questionnaires (Kennedy, Clifford, Burleigh, Jewell, \& Waggoner, 2018) we used an option offered by Mturk to (1) verify worker country location and (2) block duplicate IP addresses. What is more, we used two red herring items to check for the randomness of the answers: (1) what is the current year and 2) "Please mark a strongly agree to answer for this questions". In all studies, participants each received $\$ 0.50$ as a reward for their participation.

\section{Materials and Procedure}

After reading and accepting an informed consent, participants filled in their sociodemographic information (age, gender, and occupational status). On the following pages participants filled in the following measures, the order of which was assigned randomly.

Team preferences. The measure investigated preferences for working in a team characterized by focused vs. a shared leadership. The scale was adapted from Wood and Fields (2007) who measured the perception of actual shared leadership in a team on a four-point Likert-type scale. The scale was 
transformed for the purpose of this study and measured preference between two types of teams, e.g. 'Team A: Each member of the team participates in establishing the goals for the organization. Team B: A leader of the team establishes the goals for the organization.' Items were answered on a 5-point scale ( 1 = I would definitely like to work for Team A, 5 = I would definitely like to work for Team B.). Cronbach's alpha for the scale equaled $\alpha=.84$. On the scale level, the higher the score, the higher the preference for focused leadership in teams. The entire scale can be found in the appendix.

Control preferences were measured with scale developed by Grzelak, 2001. The shortened, 28-item scale consists of five sub-scales measuring: Collaboration (5 items, e.g. "I like being in a group in which everyone has something to say"), Dominance (5 items, e.g. "I like to have influence on what others do"), Proactive Autonomy (4 items, "I like choosing goals for myself"), Reactive Autonomy (5 items, "I don't like it when someone makes decisions about my business"), Respect for Autonomy (5 items, "It would be good if everyone were responsible for their own decisions"), and Submissiveness (4 items, "I like it when someone makes decisions for me"). Items were answered on a 5 -point scale $(1=$ Strongly disagree, $5=$ Strongly agree). The entire scale can be found in the appendix. Cronbach's alpha for the scale ranged from $\alpha=.80$ to $=.86$. The three autonomy scales were correlated at a very high level $(\mathrm{r}=.60$ for proactive autonomy and reactive autonomy, $\mathrm{r}=.60$ for reactive autonomy and autonomy respect, and $\mathrm{r}=0.77$ for autonomy respect and proactive autonomy). They also formed one factor in a factor analysis explaining $77.32 \%$ of total variance. For this reasons we decided to compute one Autonomy indicator out of the above three scales - a decision deemed appropriate in certain situations (Zinserling \& Winiewski, 2001).

Political orientation was measured with two items: "How would you describe your political outlook with regard to economic/social issues?" (Talhelm, Haidt, Oishi, Zhang, Miao, \& Chen, 2015). Response scale ranged from 1: very liberal to 7: very conservative). An indicator was computed by averaging these two items $(r=0.74)$. A higher score meant a more conservative orientation.

Personality. A 24-item Brief HEXACO Inventory (BHI) was used to measure personality (De Vries, 2013). Recent research suggests that the Big Five model fails to encompass an additional dimension that was shown to form a separate factor - Honesty-Humility (e.g. Ashton et al., 2004). The HEXACO model consists of the following personality scales: Honesty-Humility, Emotionality, eXtraversion, Agreeableness, Conscientiousness, and Openness to experience. Each of these domain scales is measured by 4 facets that capture behaviors associated with a given personality domain. The HEXACO model was shown to be a good predictor of workplace delinquency, status-driven risk-taking, egoism, narcissism, Machiavellianism, or psychopathy - all related to ModestyHumility domain, not included in the Big Five model (Ashton, Lee, Pozzebon, Visser, \& Worth, 2010; De Vries, De Vries, De Hoogh, \& Feij, 2009; De Vries \& Van Kampen, 2010; Lee, Ashton, Wiltshire, Bourdage, Visser, Gallucci, 2013). The BHI scale measures six personality domains with 1 item per facet. The alpha reliability coefficients are rather low, however the scales perform well in terms of test-retest stability and self-other agreement. It was also shown to have relatively high convergent correlations with full-length scales. Items were answered on a 5-point scale $(1=$ Strongly disagree, $5=$ Strongly agree).

\section{RESULTS}

To test our hypotheses we used a hierarchical multiple regression. We used multiple regression analysis in order to determine which of the individual difference variables are best at predicting participants' preference for shared leadership, while controlling for other variables. We regressed team preference (high values equal higher preference for focused leadership) on 1) gender ( 1 = male, 2 = female) and age in the first step in order to rule them out as alternative explanations, 
2) personality variables in the second step, 3) control preferences in the third step, and 4) political orientation in the fourth step. The results can be seen in Table 2.

For the analyzed sample, age and gender had no relationship to the team preference and neither did any of the personality variables. Among control preferences, the strongest effect could be observed for collaboration - the higher the preferences for joint outcome control, the higher the preference for shared leadership in teams, $\beta=-0.40, p<.001$. Additionally, focused leadership was preferred by those higher in preference for dominance, $\beta=0.30, p=.002$. Autonomy was not related to team preference. Finally, political orientation also predicted team preference - a more conservative (social and economic) outlook was related to higher preference for focused leadership in teams, $\beta=0.21, p=.007$.

Table 2. Results of hierarchical linear regression predicting shared leadership preferences

\begin{tabular}{|c|c|c|c|c|c|c|c|c|c|c|c|c|}
\hline & \multicolumn{3}{|c|}{ Model 1} & \multicolumn{3}{|c|}{ Model 2} & \multicolumn{3}{|c|}{ Model 3} & \multicolumn{3}{|c|}{ Model 4} \\
\hline & $\beta$ & SE & $p$ & $\beta$ & SE & $p$ & $\beta$ & SE & $p$ & $\beta$ & SE & $p$ \\
\hline Age & .01 & .01 & .558 & .01 & .01 & .201 & .01 & .01 & .221 & .01 & .01 & .449 \\
\hline Gender & -.13 & .12 & .283 & -.10 & .13 & .435 & -.07 & .12 & .582 & -.09 & .12 & .439 \\
\hline Honesty & & & & -.06 & .08 & .449 & .12 & .08 & .148 & .15 & .08 & .069 \\
\hline Emotionality & & & & .04 & .09 & .660 & .05 & .08 & .488 & .04 & .08 & .577 \\
\hline Extraversion & & & & -.09 & .08 & .270 & -.07 & .08 & .387 & -.07 & .08 & .408 \\
\hline Agreeableness & & & & .04 & .07 & .547 & .03 & .07 & .727 & -.01 & .07 & .900 \\
\hline $\begin{array}{l}\text { Openness to } \\
\text { Experience }\end{array}$ & & & & -.10 & .08 & .230 & .01 & .08 & .863 & .07 & .08 & .384 \\
\hline Conscientiousness & & & & -.19 & .10 & .066 & -.10 & .10 & .299 & -.11 & .10 & .268 \\
\hline Autonomy & & & & & & & -.10 & .11 & .359 & -.08 & .10 & .435 \\
\hline Submissiveness & & & & & & & .13 & .08 & .114 & .10 & .08 & .226 \\
\hline Dominance & & & & & & & $.28^{* *}$ & .08 & .001 & $.26^{* *}$ & .08 & .002 \\
\hline Collaboration & & & & & & & $-.38^{* * *}$ & .08 & .000 & $-.40^{* * *}$ & .08 & .000 \\
\hline Political Orientation & & & & & & & & & & $.10^{* *}$ & .04 & .007 \\
\hline $\mathrm{R}^{2}$ & & 0.01 & & & 0.11 & & & 0.29 & & & 0.32 & \\
\hline $\mathrm{F}(\mathrm{dt})$ & & $\begin{array}{c}0.8 \\
(2.173)\end{array}$ & & & $\begin{array}{c}2.46^{*} \\
(8.167)\end{array}$ & & & $\begin{array}{c}5.49^{* * * *} \\
(12.163)\end{array}$ & & & $\begin{array}{c}5.86^{* * * *} \\
(13.162)\end{array}$ & \\
\hline
\end{tabular}

\section{DISCUSSION}

The primary objective of the present study was to investigate if shared leadership is a form of organizational order that would fit everybody. If people want to work in teams that share leadership, the probability of the emergence of shared leadership will be higher and the application of shared leadership would lead to better organizational effects. We were interested in checking whether individual differences predict preference for shared vs. focused leadership. Specifically, we analyzed the relationship between personality traits, control preferences, and political orientations and preferences for shared vs. focused leadership. 


\section{Control Preferences}

Consistent with our expectations, preference for collaboration predicted higher preference for shared leadership (H1a). Grzelak (2001) argued that collaboration preference promotes democracy by accepting joint effort and coordination among individuals and social groups in attaining their interests. Collaboration requires one to give up at least some element of control over one's outcomes and accept the influence of others. Hence, those high in collaboration preference need to believe in other people's competence and good will - strong prerequisites for shared leadership.

Preference for dominance predicted higher preference for focused leadership in teams (H1c). Dominant individuals were previously shown to value success and promotion (Modrzejewska, 2004), the potential for which is arguably higher in focused leadership teams. What is more, such individuals - even if not yet in leadership positions - might envision themselves occupying one in the future - a prospect diminished in shared leadership teams. Contrary to our expectations, submissiveness was not related to preference for focused leadership in teams.

We did not form any predictions with regards to the autonomy scales. In our study the three autonomy scales (proactive autonomy, reactive autonomy, and respect for autonomy) were highly correlated, which justified collapsing them into one autonomy measure. The results of our study did not show any relationship between joint autonomy scale and preference for shared leadership. Individuals high in preference for autonomy prefer situations in which personal freedom is not limited. We can imagine both shared and focused leadership teams to promote or limit individual freedom of team members. Hence, the relationship between preference for autonomy and preference for shared leadership might be more complex and dependent on personal construal.

\section{Political Orientation}

As predicted, a conservative political orientation - in contrast to a liberal political orientation was related to higher preferences for focused leadership in teams (H2). Conservatives may be less open to shared leadership in teams as such teams violate the hierarchy of authority and social order conservatives tend to endorse (Sowell, 2002). Such teams might also be perceived as less stable and predictable (Friesen, Kay, Eibach, \& Galinsky, 2014) - attributes considered more valuable by conservatives (McCrae, 1996). In contrast, liberals were more likely to prefer shared leadership in teams. Such teams guarantee greater equality and freedom of expression - values endorsed by liberals (Sowell, 2002).

\section{Personality}

Finally, we decided to explore whether personality traits of individuals predict their preferences for shared leadership in teams. None of the personality variables proved to significantly predict preference for shared vs. focused leadership in teams. However, it is possible that people of certain personality traits might feel and fare worse in shared/focused leadership environments, without being able to predict their psychophysiological costs beforehand. Therefore, as a follow up it may be interesting to consider whether personality variable predict behavior or emotions experienced in a shared leadership context.

\section{Limitations and Future Research Directions}

Our results implicate several directions for future research. First, although in the current study control preferences were measured as relatively stable dispositions, it is important to note that they are situationally dependent (Grzelak, 2001). It is possible that individuals want to give up control in the work environment, but assume it with close others, or vice versa. Even at work, one's control preferences might depend on the level of personal significance of issues decided on by the 
team or the extent to which one's job relates to personal interests. Further research could explore these caveats.

What is more, previous research showed that a feeling of the lack of personal control might influence people's preferences for more hierarchical structures at work (Friesen et al., 2014). Further research could investigate whether perceived job or economic instability affects preferences for hierarchy via affecting people's control preferences.

In the current study, attitudes towards shared leadership were measured only on a declarative, hypothetical level. Such a situation - devoid of context, such as the number of people in the team, area of functioning, interpersonal relationships between team members, etc. - is too abstract. For instance, research showed that although self-management increased organizational citizenship behavior, if the employees did not believe that the organization trusts them, the only consequence of self-management was an increase in counterproductive work behaviors (Jensen \& Raver, 2012).

As mentioned above, due to limitations in people's ability to introspect and predict one's emotional reactions, we cannot be sure how our participants would feel in the actual shared or focused leadership teams. A study measuring employees' satisfaction and experienced emotions in shared vs. focused leadership teams would be valuable to understand the real impact of employees' individual differences (including that of personality and temperamental differences). What is more, it would be of interest to investigate the work performance of employees who either fit or do not fit into given organizational structures.

Finally, we need to address a relatively small size and homogeneity of our sample. Our participants were predominantly in full-time employment $(80.4 \%)$ and US based. A replication on different populations would be of value for generalizability of the obtained results.

\section{CONCLUSIONS}

Recent publications on shared leadership praise its ability to make employees more satisfied and organizations more effective. However, we believe that it is dangerous to assume the homogeneity of preferences. While one person finds meaning and joy in taking on responsibility at work, another one might find it a burden that pulls them away from their family or hobby. In order to prevent counterproductive behaviors from the employees forced to take on control they do not want, it is essential to identify the potential obstacles to introducing a more collaborative and egalitarian organizational structure.

Our study was aimed at investigating three individual difference variables that we assumed might predict preferences for the leadership structure. We found that both control preferences, as well as political orientations, predict preferences for shared leadership in teams. However, personality variables were not related to preferences for shared leadership. Control preferences explain individuals' willingness to enter situations of different interdependence structures. When those preferences are not met, people might experience discomfort and engage in counterproductive work behaviors. Further research should investigate to what extend control preferences can be situationally affected, as well as their impact on employee outcomes and wellbeing in shared vs. focused leadership environments.

\section{Literature}

Anderson, C., \& Galinsky, A. D. (2006). Power, optimism, and risk-taking. European Journal of Social Psycho$\log y, 36,511-536$.

Ashton, M. C., Lee, K., Perugini, M., Szarota, P., de Vries, R. E., Di Blas, L., et al. (2004). A six-factor structure of personality-descriptive adjectives: Solutions from psycholexical studies in seven languages. Journal of Personality and Social Psychology, 86, 356-366.

Ashton, M. C., Lee, K., Pozzebon, J. A., Visser, B. A., \& Worth, N. C. (2010). Status-driven risk taking and the major dimensions of personality. Journal of Research in Personality, 44, 734-737. 
Barry, D. (1991). Managing the bossless team: Lessons in distributed leadership. Organizational dynamics, 20, 31-47.

Bendahan, S., Zehnder, C., Pralong, F., P, \& Antonakis, J. (2015). Leader corruption depends on power and testosterone. The Leadership Quarterly, 26, 101-122.

Bennett, N., Wise, C., Woods, P. A., \& Harvey, J. A. (2003). Distributed leadership: A review of literature. National College for School Leadership.

Bergman, J. Z., Rentsch, J. R., Small, E. E., Davenport, S. W., \& Bergman, S. M. (2012). The shared leadership process in decision-making teams. Journal of Social Psychology, 152, 17-42.

Brown, M. E., \& Gioia, D. A. (2002). Making things click: Distributive leadership in an online division of an offline organization. The Leadership Quarterly, 13, 397-419.

Carson, J. B., Tesluk, P. E., \& Marrone, J. A. (2007). Shared leadership in teams: An investigation of antecedent conditions and performance. Academy of Management Journal, 50, 1217-1234.

Carte, T. A., Chidambaram, L., \& Becker, A. (2006). Emergent leadership in self-managed virtual teams. Group Decision and Negotiation, 15, 323-343.

Chiu, C. C., Owens, B. P., \& Tesluk, P. E. (2016). Initiating and utilizing shared leadership in teams: The role of leader humility, team proactive personality, and team performance capability. Journal of Applied Psychology, 101, 1705-1720.

Choi, C. B., \& Beamish, P. W. (2004). Split management control and international joint venture performance. Journal of International Business Studies, 35, 201-215.

Collins, D. (1995). Death of a gainsharing plan: Power politics and participatory management. Organizational Dynamics, 24, 23-38.

Daspit, J., Tillman, C. J., Boyd, N. G., \& Mckee, V. (2013). Cross-functional team effectiveness: An examination of internal team environment, shared leadership, and cohesion influences. Team Performance Management, 19, 34-56.

De Vries, R. E. (2013). The 24-item Brief HEXACO Inventory (BHI). Journal of Research in Psychology, $47,871-880$.

De Vries, R. E., \& Van Kampen, D. (2010). The HEXACO and 5DPT models of personality: A comparison and their relationships with psychopathy, egoism, pretentiousness, immorality, and machiavellianism. Journal of Personality Disorders, 24, 244-225.

De Vries, R. E., De Vries, A., De Hoogh, A., \& Feij, J. (2009). More than the Big Five: Egoism and the HEXACO model of personality. European Journal of Personality, 23, 635-654.

Denis, J. L., Lamothe, L., \& Langley, A. (2001). The dynamics of collective leadership and strategic change in pluralistic organizations. Academy of Management Journal, 44, 809-837.

Denis, J. L., Langley, A., \& Sergi, V. (2012). Leadership in the plural. The Academy of Management Annals, 6, 211-283.

Doliński, D. (1993). Orientacja defensywna. Warsaw: Wydawnictwo Instytutu Psychologii PAN.

Ensley, M. D., Hmieleski, K. M., \& Pearce, C. L. (2006). The importance of vertical and shared leadership within new venture top management teams: Implications for the performance of startups. The Leadership Quarterly, 17, 217-231.

Ensley, M. D., \& Pearce, C. L. (2001). Shared cognition in top management teams: Implications for new venture performance. Journal of Organizational Behavior: The International Journal of Industrial, Occupational and Organizational Psychology and Behavior, 22, 145-160.

Etzioni, A. (1965). Dual leadership in complex organizations. American Sociological Review, 30, 688-698.

Etzioni, A., \& Lehman, E. (1968). Dual leadership in a therapeutic organization. Revue Internationale De Psychologie Appliquée, 17, 51-67.

Fausing, M. S., Joensson, T. S., Lewandowski, J., \& Bligh, M. (2015). Antecedents of shared leadership: Empowering leadership and interdependence. Leadership and Organization Development Journal, 36, 271-291.

Finch, F. E. (1977). Collaborative leadership in work settings. Journal of Applied Behavioral Science, 13, 292-302.

Fiske, S. T. (1993). Controlling other people. The impact of power on stereotyping. 48, 621-628.

Friesen, J. P., Kay, A. C., Eibach, R. P., Galinsky, A. D. (2014). Seeking structure in social organization: Compensatory control and the psychological advantages of hierarchy, Journal of Personality and Social Psychology, 106, 590-609.

Gibb, C. A. (1954). Leadership. In G. Lindzey (Ed.), Handbook of Social Psychology vol. 2, (pp. 877-920). Reading, MA: Addison-Wesley.

Goksoy, S. (2016). Analysis of the relationship between shared leadership and distributed leadership. Eurasian Journal of Educational Research, 65, 295-312.

Gonzaga, G. C., Keltner, D., \& Ward, D. (2008). Power in mixed-sex stranger interactions. Cognition and Emotion, 22, $1555-1568$. 
Grille, A., Schulte, E.-M., \& Kauffeld, S. (2015). Promoting shared leadership: A multilevel analysis investigating the role of prototypical team leader behavior, psychological empowerment, and fair rewards. Journal of Leadership and Organizational Studies, 22, 324-339.

Gronn, P. (2002). Distributed leadership as a unit of analysis. The Leadership Quarterly, 13, 423-451.

Grzelak, J. (2002). O orientacji kontroli. In J. Brzeziński \& H. Sęk (Eds.), Psychologia w obliczu nadchodzących przemian społeczno-kulturowych. Kolokwia Psychologiczne vol. 10, (pp. 239-253). Warsaw, Poland: Instytut Psychologii PAN.

Grzelak, J. (2001). Control preferences. In J. A. Bargh \& D. K. Apsley (Eds.), Unraveling the Complexities of Social Life (pp. 141-154). Washington, DC: American Psychological Association.

Grzelak, J., Kuhlman, D. M., Yeagley, E. and Joireman, J. (2010). Attraction to Prospective Dyadic Relationships: Effects of Fate Control, Reflexive Control and Partner's Trustworthiness. In Kramer, R., Tenbrunsel, A., and Bazerman, M. (Eds) Social Decision Making: Social Dilemmas, Social Values and Ethical Judgments. Routledge.

Gu, J., Chen, Z., Huang, Q., Liu, H., \& Huang, S. (2018). A multilevel analysis of the relationship between shared leadership and creativity in inter-organizational teams. The Journal of Creative Behavior, 52, 109-126.

Guinote, A., Judd, C. M., \& Brauer, M. (2002). Effects of power on perceived and objective group variability: Evidence that more powerful groups are more variable. Journal of Personality and Social Psychology, 82, 708-721.

Han, S. J., Lee, Y., Beyerlein, M., \& Kolb, J. (2018). Shared leadership in teams: The role of coordination, goal commitment, and knowledge sharing on perceived team performance. Team Performance Management, $24,150-168$.

Hiller, N. J., Day, D. V., \& Vance, R. J. (2006). Collective enactment of leadership roles and team effectiveness: A field study. Leadership Quarterly, 17, 387-397.

Hoch, J. E. (2014). Shared leadership, diversity, and information sharing in teams. Journal of Managerial Psychology, 29, 541-564.

Hoch, J. E. (2013). Shared leadership and innovation: The role of vertical leadership and employee integrity. Journal of Business and Psychology, 28, 159-174.

Hoch, J. E., \& Dulebohn, J. H. (2017). Team personality composition, emergent leadership and shared leadership in virtual teams: A theoretical framework. Human Resource Management Review, 27, 678-693.

Hoch, J. E., \& Kozlowski, S. W. J. (2014). Leading virtual teams: Hierarchical leadership, structural supports, and shared team leadership. Journal of Applied Psychology, 99, 390-403.

Hoch, J. E., Pearce, C. L., \& Welzel, L. (2010). Is the most effective team leadership shared? the impact of shared leadership, age diversity, and coordination on team performance. Journal of Personnel Psychology, 9, 105-116.

Hogeveen, J., Inzlicht, M., \& Obhi, S. S. (2014). Power changes how the brain responds to others. Journal of Experimental Psychology: General, 143, 755-762.

Hu, N., Chen, Z., Gu, J., Huang, S., \& Liu, H. (2017). Conflict and creativity in inter-organizational teams: The moderating role of shared leadership. International Journal of Conflict Management, 28, 74-102.

Huxham, C., \& Vangen, S. (2000). Leadership in the shaping and implementation of collaboration agendas: How things happen in a (not quite) joined-up world. Academy of Management Journal, 43, 1159-1175.

Ishikawa, J. (2012). Transformational leadership and gatekeeping leadership: The roles of norm for maintaining consensus and shared leadership in team performance. Asia Pacific Journal of Management, 29, 265-283.

Jensen, J. M., \& Raver, J. L. (2012). When self-management and surveillance collide. Consequences for employees' organizational citizenship and counterproductive work behaviors. Group and Organization Management, 37, 308-346.

Jost, J. T. (2006). The end of the end of ideology. American Psychologist, 61, 651-670.

Jost, J. T., Glaser, J., Sulloway, F., \& Kruglanski, A. W. (2003). Political conservatism as motivated social cognition. Psychological Bulletin, 129, 339-375.

Kelley, H. H., Thibaut, W. (1978). Interpersonal relations. A theory of interdependence, New York: Wiley.

Keltner, D., Gruenfeld, D.H. \& Anderson, C. (2003) Power, approach, and inhibition. Psychological Review, $110,265-284$.

Kennedy, R., Clifford, S., Burleigh, T., Jewell, R., \& Waggoner, P. (2018). The Shape of and Solutions to the MTurk Quality Crisis. Available at SSRN: https://ssrn.com/abstract=3272468 or http://dx.doi.org/10.2139/ ssrn. 3272468

Kipnis, D. (1972). Does power corrupt? Journal of Personality and Social Psychology, 24, 33-41.

Klakovich, M. D. (1994). Connective leadership for the 21st-century - A historical-perspective and future-directions. Advances in Nursing Science, 16, 42-54. 
Klakovich, M. D. (1996). Registered nurse empowerment - Model testing and implications for nurse administrators. Journal of Nursing Administration, 26, 29-35.

Laloux, F. (2014). Reinventing organizations: A guide to creating organizations inspired by the next stage in human consciousness. Brussels: Nelson Parker.

Lambie, J. A., \& Marcel, A. J. (2002). Consciousness and the varieties of emotion experience: a theoretical framework. Psychological Review, 109, 219-259.

Lee, K., Ashton, M. C., Wiltshire, J., Bourdage, J. S., Visser, B. A., \& Gallucci, A. (2013). Sex, Power, and Money: Prediction from the Dark Triad and Honesty-Humility. European Journal of Personality, 27, 169-184.

Lee, D. S., Lee, K. C., \& Seo, Y. W. (2015). An analysis of shared leadership, diversity, and team creativity in an e-learning environment. Computers in Human Behavior, 42, 47-56.

Lord, R. G., Day, D. V., Zaccaro, S. J., Avolio, B. J., \& Eagly, A. H. (2017). Leadership in applied psychology: Three waves of theory and research. Journal of Applied Psychology, 102, 434-451.

Mathieu, J. E., Kukenberger, M. R., D’innocenzo, L., \& Reilly, G. (2015). Modeling reciprocal team cohesion-performance relationships, as impacted by shared leadership and members' competence. Journal of Applied Psychology, 100, 713-734.

McCrae, R. R. (1996). Social consequences of experiential openness. Psychological Bulletin, 120, 323-337.

McCrae, R. R., \& John, O. P. (1992). An introduction to the five-factor model and its applications. Journal of Personality, 60, 175-215.

McCrimmon, M. (2005). Thought leadership: A radical departure from traditional, positional leadership. Management Decision, 43, 1064-1070.

Modrzejewska, I. (2004). Satysfakcja zawodowa, wartości zawodowe a preferencje kontroli u pracowników zatrudnionych $w$ organizacji prywatnej i państwowej (unpublished master's thesis). Warsaw: Faculty of Psychology, University of Warsaw, Warsaw, Poland.

Nonaka, I., Hirose, A., \& Takeda, Y. (2016). 'Meso'-foundations of dynamic capabilities: team-level synthesis and distributed leadership as the source of dynamic creativity. Global Strategy Journal, 6, 168-182.

Pearce, C. L. (2007). The future of leadership development: The importance of identity, multi-level approaches, self-leadership, physical fitness, shared leadership, networking, creativity, emotions, spirituality and on-boarding processes. Human Resource Management Review, 17, 355-359.

Pearce, C. L., \& Conger, J. A. (2003). Shared Leadership: Reframing the Hows and Whys of Leadership. Thousand Oaks, Calif: SAGE Publications, Inc.

Pearce, C. L., Hoch, J., Jeppesen, H., \& Wegge, J. (2010). New forms of management: shared and distributed leadership in organizations. Personnel Psychology, 9, 151-153.

Pearce, C. L., \& Sims, H. P. (2002). Vertical versus shared leadership as predictors of the effectiveness of change management teams: An examination of aversive, directive, transactional, transformational, and empowering leader behaviors. Group Dynamics-Theory Research and Practice, 6, 172-197.

Pearce, C. L., \& Sims, H. P. J. (2000). Shared leadership: Toward a multi-level theory of leadership. In M. Beyerlein, D. A. Johnson, \& S. T. Beyerlein (Eds.), Advances in interdisciplinary studies of work teams: Team development (Vol. 7, pp. 115-139). New York: Elsevier.

Pratto, F., Sidanius, J., Stallworth, L. M., \& Malle, B. F. (1994). Social dominance orientation: A personality variable predicting social and political attitudes. Journal of personality and social psychology, 67, 741.

Robert, L. P., \& You, S. (2018). Are you satisfied yet? Shared leadership, individual trust, autonomy, and satisfaction in virtual teams. Journal of the Association for Information Science and Technology, 69, $503-513$.

Sally, D. (2002). Co-leadership: Lessons from republican Rome. California Management Review, 44, 84-99.

Semler, R. (2001). Maverick!: the success story behind the world's most unusual workplace. London: Arrow.

Serban, A., \& Roberts, A. J. B. (2016). Exploring antecedents and outcomes of shared leadership in a creative context: A mixed-methods approach. Leadership Quarterly, 27, 181-199.

Sowell, T. (2002). A conflict of visions: The ideological origins of political struggles. New York: Basic Books.

Talhelm, T., Haidt, J., Oishi, S., Zhang, X., Miao, F. F., \& Chen, S. (2015). Liberals think more analytically (more "WEIRD") than conservatives. Personality and Social Psychology Bulletin, 41, 250-267.

Thorpe, R., Gold, J., \& Lawler, J. (2011). Locating distributed leadership. International Journal of Management Reviews, 13, 239-250.

Uhl-Bien, M. (2006). Relational leadership theory: Exploring the social processes of leadership and organizing. Leadership Quarterly, 17, 654-676.

Ulhøi, J. P., \& Müller, S. (2014). Mapping the landscape of shared leadership: A review and synthesis. International Journal of Leadership Studies, 8, 66-87.

van Kleef, G. A., Oveis, C., van der Löwe, I., LuoKogan, A., Goetz, J., \& Keltner, D. (2008). Power, distress, and compassion: Turning a blind eye to the suffering of others. Psychological Science, 19, 1315-1322. 
Vangen, S., \& Huxham, C. (2003). Enacting leadership for collaborative advantage: Dilemmas of ideology and pragmatism in the activities of partnership managers. British Journal of Management, 14, 61-76.

Wang, D., Waldman, D. A., \& Zhang, Z. (2014). A meta-analysis of shared leadership and team effectiveness. Journal of Applied Psychology, 99, 181-198.

Wood, M. S., \& Fields, D. (2007). Exploring the impact of shared leadership on management team member job outcomes. Baltic Journal of Management, 2, 251-272.

Wu, Q., \& Cormican, K. (2016). Shared Leadership and Team Creativity: a Social Network Analysis in Engineering Design Teams. Journal of technology management \& innovation, 11, 2-12.

Wu, W. P., \& Lee, Y. D. (2001). Participatory management and industrial relations climate: A study of Chinese, Japanese and US firms in Taiwan. International Journal of Human Resource Management, 12, 827-844.

Zhou, W., Zhang, Y., \& Shen, Y. (2017). How shared leadership and team personality composition interact to improve entrepreneurial team performance: Evidence from china. Journal of Small Business and Enterprise Development, 24, 426-445.

Zinserling, I., \& Winiewski, M. (2011). Uwarunkowania orientacji kontroli. 15 lat badań Inwentarzem Upodobań i Opinii (IUiO). In J. Czarnota-Bojarska \& I. Zinserling (Eds.), W kręgu psychologii społecznej (pp. 37-58), Warsaw, Poland: Wydawnictwa Uniwersytetu Warszawskiego. 


\section{APPENDIX}

\section{Shared vs. Focus Leadership Scale}

- Team A: Each member of the team participates in establishing the goals for the organization. Team B: A leader of the team establishes the goals for the organization.

- Team A: The team has one leader who takes on the responsibility for the team outcomes and guides the team members. Team B: Each team member shares the responsibility for the team outcomes and helps in guiding others. (Reversed)

- Team A: Each team member helps to frame the vision for the organization. Team B: A leader of the team frames the vision for the organization.

- Team A: The team has one person in charge who ensures that the work is well organized. Team B: The team members collaborate to organize the workflow. (Reversed)

- Team A: Each member shares in deciding on the best course of action when a problem faces the team. Team B: A leader decides on the best course of action when a problem faces the team.

- Team A: A leader insures the team fulfills its obligations. Team B: Each member chip in (even if it is outside an area of personal responsibility) to insure the team fulfills its obligations. (Reversed)

- Team A: Each member is evaluated by and is accountable to all other members of the team. Team B: Each member is evaluated by and is accountable to a leader of the team.

- Team A: A leader decides how resources are allocated in regard to the team's priorities. Team B: Each member has a say in deciding how resources are allocated in regard to the team's priorities. (Reversed)

- Team A: Team members collaborate with one another in making decisions that affect the organization. Team B: A leader makes decisions that affect the organization.

- Team A: A leader identifies, diagnoses, and resolves the problems that face the team. Team B: Each member helps to identify, diagnose, and resolve the problems that face the team. (Reversed)

Control Preferences Scale (Grzelak, 2001)

\begin{tabular}{|c|c|}
\hline Collaboration & $\begin{array}{l}\text { I like being in a group in which everyone has an influence on what happens } \\
\text { I like being in a group in which everyone has something to say } \\
\text { It is best to solve a problem together with others } \\
\text { I like being in a group in which everyone makes decisions together } \\
\text { I like working in a team }\end{array}$ \\
\hline Dominance & $\begin{array}{l}\text { I like making decisions for others } \\
\text { I like leading other people } \\
\text { I think I have leadership tendencies } \\
\text { I like to have influence on what others do } \\
\text { I like to wield power }\end{array}$ \\
\hline Proactive Autonomy & $\begin{array}{l}\text { I like taking care of my own business myself } \\
\text { I like controlling my own fate } \\
\text { I like choosing goals for myself } \\
\text { I like taking care of myself }\end{array}$ \\
\hline Reactive Autonomy & $\begin{array}{l}\text { I don't like it when someone interferes in my life } \\
\text { I don't like it when someone rules over me } \\
\text { I don't like it when someone makes decisions about my business } \\
\text { I don't like it when someone forces their opinion on me } \\
\text { I don't like it when someone butts into what I'm doing }\end{array}$ \\
\hline Respect for Autonomy & $\begin{array}{l}\text { I like people who lead their own lives } \\
\text { I like people who are masters of their own fate } \\
\text { It would be good if everyone were responsible for their own decisions } \\
\text { I like people who are autonomous, independent from others } \\
\text { I like it when other people can think for themselves }\end{array}$ \\
\hline Submissiveness & $\begin{array}{l}\text { I like it when someone directs me in various things } \\
\text { I am readily subordinate to others on a day to day basis } \\
\text { I like it when someone makes decisions for me } \\
\text { I like it when someone is responsible for me }\end{array}$ \\
\hline
\end{tabular}

